\title{
Investigating the Determinants of App-based Land Transportation User Loyalty in Jakarta Using PLS-SEM Framework
}

\author{
Michael Christian ${ }^{1 *}$, Farida Jasfar ${ }^{2}$, Hamdy $\mathrm{Hady}^{3}$ \\ ${ }^{1}$ Service Management, Universitas Trisakti, Jakarta \\ ${ }^{2}$ Faculty of Economics and Business, Universitas Trisakti, Jakarta \\ ${ }^{3}$ Universitas Persada Indonesia YAI, Jakarta \\ *Corresponding author email: michaelchristianid@gmail.com
}

Received: 02 January 2021 / Revised: 25 January 2021 / Accepted: 02 February 2021 / Published: 09 February 2021

\begin{abstract}
This study aims to investigate user loyalty factors using application-based land transportation in Jakarta. The methodology in this study uses a quantitative approach and a questionnaire is used as an instrument to collect data. With an unknown population, this study used 301 samples of application-based land transportation users. The statistical method used to analyze the hypotheses in this study is Partial Least Square - Structural Equation Modeling (PLS-SEM) with WARP-PLS. Based on the results of statistical tests, it was found that 6 hypotheses were accepted, and 5 hypotheses were rejected. The result of this study explains that ease of using the application affects the loyalty in using application-based transportation. Meanwhile, loyalty is not influenced by application display, service responsiveness in applications, service adjustment, service guarantee and user attitudes. This research further explains that the ease of using the application, application display, service adjustment, and service guarantee affect the user's attitude. On the other hand, service responsiveness does not affect attitude towards using. As novelty, the use of the loyalty framework in this study uses the use attitude as a mediator of main factors in service quality for application-based transportation in urban areas. As a managerial implication, it is interesting that the results of this study explain that loyalty in the use of applicationbased transportation is not automatically formed from a positive attitude towards using. The adjustment of services provided on the application because of competition in the application-based transportation industry must be able to meet user expectations which tend to change according to the offers provided by service providers.
\end{abstract}

Keywords: transportation, attitude, loyalty

\section{Introduction}

Loyalty in the use of land transportation for the urban public is a difficult job for transportation service providers to achieve. Globally, public transportation modes are undergoing a transformation due to increased urban mobility driven by several factors relating to psychological to economic factors (Eboli \& Mazzulla, 2012). The more available modes of transportation that offer advantages to users, the higher the tendency for users to choose. However, the increasing number of existing modes of transportation makes this a boomerang. On the one hand, it is easier to get and at the same time choose certain modes of transportation, but on the other hand, traffic jams cannot be avoided. Urban areas such as Jakarta with the largest population in the world (Nadi \& Murad, 2019) have endless transportation problems and tend to be increasingly complex. Urban areas are known to have problems with regulating public transport due to the complexities involved such as road land use, noise, and air pollution. Not only Jakarta, in 2011 Hickman, Fremer, Breithaupt, \& Saxena in a book entitled "Changing Course in Urban Transport" also agreed that transportation problems are quite complex in several big cities in the world such as Alepo, Beijing, Delhi, Manila, San Diego, and Toronto. In Jakarta, it is often found that many modes of transportation stop on the road to wait, pick up and drop off passengers out of place. This has resulted in the flow of transportation 
Investigating the Determinants of App-based Land Transportation User Loyalty in Jakarta Using PLS-SEM Framework

on the road not smooth. In addition, this can make users of public transportation unsafe and uncomfortable because of the chaotic services provided. People sometimes fear that pedestrians or sidewalks lose their function (Hidayati, Yamu, \& Tan, 2020). This makes public transportation a "forced" choice to choose due to user needs. In the long term this will make this public transportation mode abandoned by passengers along with the offer of better services such as application-based transportation modes (Gojek and Grab). Application-based transportation recently comes with offering several solutions to answer existing problems. The solutions offered continue to adapt and complement the needs of users in Jakarta. The concept of service quality that continues to be adjusted and improved makes this mode of transportation one of the differentiated modes of public transportation in urban areas to shape user attitudes, usage intentions and user satisfaction. One of the indicators of satisfaction with the use of public transportation is the level of safety in preventing death due to accidents that occur (Cheba \& Saniuk, 2016). Not much different from Negi (2010) which explains that customer satisfaction considers quality of service as a whole of value for customers. Easy use of ordering allows users to have more control over destinations such as the type of transportation mode (motorbike or car), pick-up points, road routes, and destination points. Thus, the performance of the services provided, the existing travel routes, the transportation system of the applications provided creates user satisfaction (Mugion, Toni, Raharjo, Pietro, \& Sebathu, 2018). On the other side, this is also beneficial for providers of transportation modes where user satisfaction is formed that can support organizational sustainability (Mokonyama \& Venter, 2013; Lai \& Chen, 2011; Rita \& Ganesan, 2010). As a result of the competitive process in the public transportation industry, gaining user loyalty has become a more difficult task for application-based transportation service providers. Competition does not only come from conventional public transportation modes, but also from fellow application-based transportation service providers. Along with Grab's acquisition of Uber in Indonesia, the main players in this industry are Gojek and Grab. The attitude of users to remain loyal using one of these application-based modes of transportation is exceedingly difficult to establish. The tendency to switch brands of applicationbased transportation modes is quite high. Apart from being influenced by price, factors such as ease of use of the application, user-friendly appearance of the application, fast response, and adjustments to other service offerings also affect user tastes. Although in several research studies it is clear that one of the keys to loyalty lies in providing quality for customer satisfaction (Azzahro et al., 2020; Hendrayati, Askolani, Achyarsyah, Sudrajat, \& Syahidah, 2020; Siangta, Solichin, \& Hendriana, 2020), however service providers still find it difficult to maintain the quality of these services consistently. Therefore, the attitude of users to persist in using an application-based transportation mode brand will tend to change. Based on this, it can be explained that there is still a gap in explaining the attitude and loyalty of using application-based transportation modes in Jakarta which are based on the core factors of service quality. The originality of this study lies in a specific research model that uses the core factors of service quality in the applicationbased transportation sector with user attitudes as a mediator to determine usage loyalty. Thus, it can be explained that this study aims to investigate the determinants of user loyalty in application-based modes of transportation.

\section{Literature Review}

\subsection{Loyalty}

The term loyalty related to the aspect of satisfaction describes the comparison of the end result and consumer expectations (Oliver, 2010). In simple terms, service providers should consider key factors, namely what consumers expect and what customer satisfaction is. In public transportation, the result of the service can be explained by what users feel, starting from the process of ordering the transportation mode until the user arrives at the destination. Cheba \& Saniuk (2016) in their research in European Union countries explained that satisfaction with the use of public transportation is an integral part of the social impact of developing urban transportation. This study also further explains that the factors that determine satisfaction in the use of public transportation, one of which is the level of security in an urban area. 
Michael Christian et al., Adv. J Social Sci.; Vol. 8, Issue 1, pp: 25-36, 2021

Literatures analyze public transportation from various aspects such as service quality which affects overall satisfaction by relating aspects such as the mode of transportation used, personal attitudes to the use of public transportation modes and the urban context. The relationship between the overall satisfaction of public transportation users with the use of public transportation modes is explained from several studies. Mugion et al., (2018) explain that there is a significant influence between the overall satisfaction of public transportation users on the loyal attitude of using more of public transportation in Rome, Italy. Likewise, with research conducted by Hussein \& Hapsari (2014) which states that the user's satisfaction attitude towards public transportation Tranjakarta has an impact on the user's desire to be loyal.

\subsection{Attitude towards using}

Many researchers explain that the determinants of user preferences in public transportation are comfort, clean conditions, information about the route of vehicle conditions and overall stops, safety, availability of seats, network coverage, driver attitudes and time efficiency. Hussein \& Hapsari (2014) use four attributes in explaining user satisfaction of public transportation where one of the attributes is the right decision to use TransJakarta to travel. Meanwhile, Mugion et al., (2018) in explaining the attitudes of public transportation users use attributes such as a sense of satisfaction from the services provided, a sense of satisfaction with existing travel routes, a sense of satisfaction with the transportation system provided. According to Rahadianto, Maarif, \& Yuliati (2019), Ng \& Phuong (2015) and (Sumaedi, Bakti, \& Yarmen, 2012), it is clear that individual desires shape decisions to use a particular mode of public transportation. The attributes used in explaining loyal attitudes to the use of transportation modes are the desire to use the next public transportation mode and the intention to switch private vehicles to public transportation modes (Mugion et al., 2018; Zailani, Iranmanesh, Masron, \& Chan, 2016). In other words, the attitude of users who have a strong desire reflects a form of use loyalty.

\subsection{Service quality}

The concept of quality of service from Parasuraman is still popularly used in various scopes. Service quality can be explained simply as a comparison of expectations and perceptions. Therefore, the gap between what the customer expects and what the customer perceives will continue to occur but needs to be addressed as soon as possible for the sake of long-term business targets. Service quality is an important factor for all businesses, including the public transportation sector because it can affect customer satisfaction, type of transportation mode, and user expectations (Anderson, Condry, Findlay, Brage-Ardao, \& Li, 2014). Amponsah \& Adams (2016) explains based on the basic concepts of Gronros, Lehtinen and Parasuraman about service quality, where service quality is related to the form of assessment of how well the services provided can meet customer expectations. Fulfilled expectations can shape user loyalty. Measurement of service quality in the public transport sector has been described in several studies using several dimensions. According to Jao-Hong, Chien Yuan, Huei-Ping, \& Chun-Liang (2010) explains that service quality in "bus" public transportation uses several dimensions, namely empathy, assurance, reliability, responsiveness, and tangibility. Meanwhile, Allen, Muñoz, \& Ortúzar, (2019) in their research on metro public transportation and transit stops used the dimensions of security, drivers, information, complementary facilities, ticketing, smooth transit, transit area conditions, response to emergency matters, and total satisfaction. Then, Mugion et al., (2018) in explaining service quality uses the attributes of feeling safe using application-based transportation, convenience, reasonableness of waiting time, application system reliability, and duration of travel time according to expectations. Several studies in recent years explained the relationship between the quality of public transportation services and usage behaviour. In public transportation in the city of Rome, Italy, for example, it is explained that the quality of public transportation services affects user attitudes which can form loyalty for public transportation users (Mugion et al., 2018). Likewise, research conducted by Amponsah \& Adams (2016) explains that there is a significant influence between the quality of transportation services on the attitude to use again. Meanwhile, Jao-Hong et al., (2010) in their research on buses in Taiwan explained that the efficiency and quality of services provided affect the attitude of using 
Investigating the Determinants of App-based Land Transportation User Loyalty in Jakarta Using PLS-SEM Framework

public transportation. The research emphasizes the attributes of waiting time for the mode of transportation and the reliability of the transportation system.

\subsection{Conceptual framework and Hypothesis}

Based on the explanation above, figure 1 explains the conceptual framework of this study, as follows:

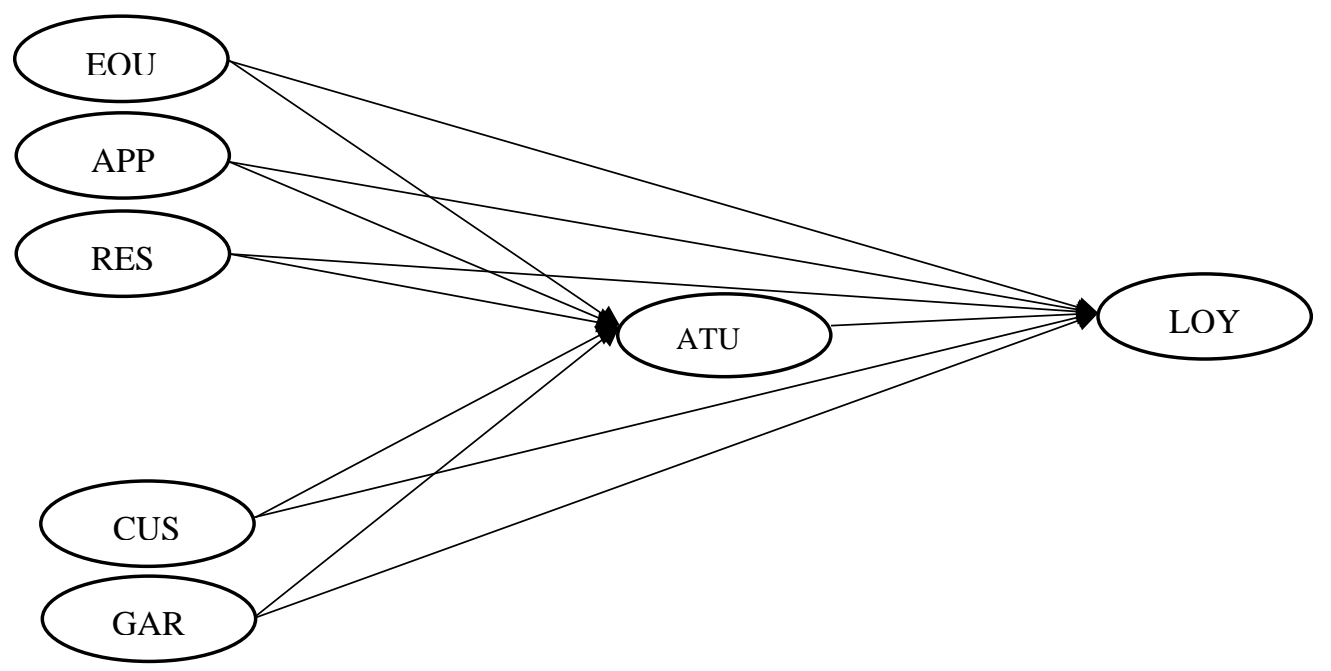

Note: $\mathrm{EOU}=$ Ease of use; APP = Display Application; RES = Responsiveness; CUS = Customisation; GAR = Guarantee; ATU $=$ Attitude towards using; LOY = Loyalty

Figure 1: Conceptual framework

From the conceptual framework above, this research proposes the hypotheses in table 1 as follows:

Table 1: Research Hypothesis

\begin{tabular}{ll}
\hline Research Hypothesis \\
\hline H1: & Ease of use influences attitude towards using \\
H2: & The display application influences attitude towards using \\
H3: & Responsiveness influences attitude towards using \\
H4: & Customization influences attitude towards using \\
H5: & Guarantee influences attitude towards using \\
H6: & Ease of use influences loyalty \\
H7: & Display application influences loyalty \\
H8: & Responsiveness influences loyalty \\
H9: & Customization influences loyalty \\
H10: & Guarantee influences loyalty \\
H11: & Attitude towards using influences loyalty \\
\hline
\end{tabular}

\section{Methodology}

This research is a quantitative study using a survey method with an online questionnaire. The questionnaire was arranged with a Likert scale of 1 (Strongly Disagree) to 5 (Strongly Agree). The inclusion criteria in this study were users of online transportation modes (Gojek and / or Grab) in Jakarta who used these online modes of transportation in the last 3 months since the research was conducted. This is to get measurements from experiences that are still easy to remember. Thus, users outside the Jakarta area and who have no experience or more than 3 months of using online transportation are not the criteria in this study (exclusion criteria). To ensure the eligibility of the sample criteria, at the beginning of the questionnaire asked about the profile of the respondent where the questions are in accordance with the criteria determined in this 
Michael Christian et al., Adv. J Social Sci.; Vol. 8, Issue 1, pp: 25-36, 2021

study. The location of this research is in Jakarta with application-based land transportation users as the sample collected by purposive random sampling technique. Data collection was carried out from June 2018 to February 2020. There were 337 questionnaires entered. Then filtering is carried out according to the specified sample criteria. From the number of questionnaires that were received, 301 questionnaires $(89.32 \%)$ were eligible for analysis. This number still meets the minimum sample requirements in the criteria for this study. According to Hair, Black, Babin, \& Anderson (2014), looking for the sample size from an unknown population, namely the multiplication of the number of indicators by 5 to 10 . Thus, the sample size is still appropriate for the number of 40 indicators. The dimensions used to explain loyalty (El-Manstrly \& Harrison, 2013) in this study are cognitive loyalty (5 items), affective loyalty (5 items), conative loyalty (4 items), and action loyalty (4 items). Lee, Tsao, \& Chang (2015) explained using the dimensions of feeling using ( 2 items) and perceived value (3 items). Furthermore, the service quality variables (Ribbink, Riel, Liljander, \& Streukens, 2004) use the dimensions of ease of use (4 items), application display (4 items), responsiveness (3 items), adjustment (3 items), and warranty (3 items). Data analysis uses Partial Least Square - Structural Equation Modeling (PLS-SEM) with WARPPLS. To complete the data analysis, a series of tests were carried out, namely the reliability and validity test, model fit, hypothesis testing, and the coefficient of determination.

\section{Results}

\subsection{Profile of respondents}

The respondent profile in table 2 shows information such as gender, the most frequently used mode of transportation, the costs incurred in one trip, and the most frequently used application-based transportation brands.

Table 2: Respondent Profile

\begin{tabular}{lcc}
\hline Variable & $\mathbf{n = 3 0 1}$ & $\mathbf{\%}$ \\
\hline Gender & 113 & 37.5 \\
Male & 188 & 62.5 \\
Female & & \\
Mode of transportation & 258 & 258 \\
2-wheeled & 43 & 43 \\
4-wheeled & & \\
Costs & 186 & 61.8 \\
$\leq$ Rp. 25,000 & 69 & 22.9 \\
Rp. 25,001 - Rp. 50,000 & 46 & 15.3 \\
$>$ Rp. 50,000 & & \\
Brands & 200 & 66.4 \\
Grab & 101 & 33.6 \\
Gojek & & \\
\hline
\end{tabular}

Data in this study consisted of 188 women $(62.5 \%)$ as users of application-based transportation modes and the remaining 113 men (37.5\%) as users of application-based modes of transportation. Based on the type of transportation mode, 258 respondents $(85.7 \%)$ most often used 2-wheeled transportation (motorbikes) and the remaining 43 respondents $(14.3 \%)$ most often used 4-wheeled transportation (cars). From the aspect of costs incurred for one trip, 186 respondents (61.8\%) spent up to Rp. 25,000, 69 respondents (22.9\%) spent Rp. 25,001 - Rp. 50,000, while the rest 46 respondents (15.3\%) are more than Rp. 50,000. Based on the most frequently used application-based mode of transportation, it can be explained that 200 respondents (66.4\%) used Grab the most and 101 respondents (33.6\%) used Gojek the most. 
Investigating the Determinants of App-based Land Transportation User Loyalty in Jakarta Using PLS-SEM Framework

\subsection{Validity and reliability}

Table 3 shows the results of the validity and reliability tests.

Table 3: Validity and Reliability Test

\begin{tabular}{|c|c|c|c|c|}
\hline \multirow[b]{2}{*}{$\begin{array}{l}\text { Variables and } \\
\text { indicators }\end{array}$} & \multicolumn{2}{|c|}{$\begin{array}{l}\text { Validity } \\
\end{array}$} & \multicolumn{2}{|c|}{ Reliability } \\
\hline & $\begin{array}{l}\text { Convergent } \\
\text { validity (AVE } \geq \\
0.50 \text { ) }\end{array}$ & $\begin{array}{l}\text { Discriminant validity } \\
\text { (loading factor } \geq 0.70 \text { ) }\end{array}$ & $\begin{array}{l}\text { Composite } \\
\text { Reliability } \\
(\mathrm{CR} \geq \mathbf{0 . 7 0 )}\end{array}$ & $\begin{array}{l}\text { Cronbach's } \\
\text { Alpha (CA } \geq \\
\text { 0.70) }\end{array}$ \\
\hline Ease of use & 0,688 & - & 0.898 & 0.848 \\
\hline EOU1 & - & 0.859 & & \\
\hline EOU2 & - & 0.862 & & \\
\hline EOU3 & - & 0.772 & & \\
\hline EOU4 & - & 0.823 & & \\
\hline Display Application & 0,645 & - & 0.879 & 0.816 \\
\hline APP1 & - & 0.755 & & \\
\hline APP2 & - & 0.799 & & \\
\hline APP3 & - & 0.821 & & \\
\hline APP4 & - & 0.837 & & \\
\hline Responsiveness & 0,673 & - & 0.860 & 0.756 \\
\hline RES1 & - & 0.816 & & \\
\hline RES2 & - & 0.786 & & \\
\hline RES3 & - & 0.857 & & \\
\hline Customisation & 0,772 & - & 0.910 & 0.852 \\
\hline CUS1 & - & 0.900 & & \\
\hline CUS2 & - & 0.888 & & \\
\hline CUS3 & - & 0.847 & & \\
\hline Guaratee & 0,742 & - & 0.896 & 0.826 \\
\hline GAR1 & - & 0.837 & & \\
\hline GAR2 & - & 0.894 & & \\
\hline GAR3 & - & 0.852 & & \\
\hline Attitude & 0,747 & - & 0.937 & 0.915 \\
\hline ATU1 & - & 0.858 & & \\
\hline ATU2 & - & 0.889 & & \\
\hline ATU3 & - & 0.881 & & \\
\hline ATU4 & - & 0.879 & & \\
\hline ATU5 & - & 0.812 & & \\
\hline Loyalty & 0,632 & - & 0.957 & 0.951 \\
\hline LOY1 & - & 0.757 & & \\
\hline LOY2 & - & 0.776 & & \\
\hline LOY4 & - & 0.790 & & \\
\hline LOY5 & - & 0.770 & & \\
\hline LOY6 & - & 0.829 & & \\
\hline LOY7 & - & 0.832 & & \\
\hline LOY8 & - & 0.847 & & \\
\hline LOY9 & - & 0.822 & & \\
\hline LOY10 & - & 0.861 & & \\
\hline LOY11 & - & 0.755 & & \\
\hline LOY12 & - & 0.799 & & \\
\hline LOY15 & - & 0.758 & & \\
\hline LOY16 & - & 0.728 & & \\
\hline
\end{tabular}


Michael Christian et al., Adv. J Social Sci.; Vol. 8, Issue 1, pp: 25-36, 2021

The validity test uses convergent and discriminant concept. Convergent validity looks at the results of Average Variance Extracted (AVE) where the standard must be $\geq 0.50$ (Kock, 2018). All the results on the variables in table 3 show the results $\geq 0.50$ so it can be said that all variables in this study are valid and meet the measurement standards. The standard for discriminant validity is the loading factor value $\geq 0.70$. Table 3 show that all indicators have a loading factor of $\geq 0.70$. Thus, all indicators are also valid and meet measurement standards. Furthermore, to determine the reliability test, Composite Reliability (CR) the standard must be $\geq 0.70$ and Cronbach's Alpha (CA) must be $\geq 0.70$ (Kock, 2018). Based on table 3, Composite Reliability on all variables shows $C R \geq 0.70$ and Cronbach's Alpha for all variables show $C A \geq$ 0.70 . With these results it can be said that all variables in this study are reliable.

\subsection{Model fit}

Table 4 shows the results of the model fit test.

Table 4: Model Fit Test

\begin{tabular}{lll}
\hline Model fit and quality indices & Results & Standard of measurements \\
\hline Average path coefficient (APC) & $\mathrm{APC}=0.176$ & $\mathrm{P}<0.001$ \\
Average R-squared (ARS) & $\mathrm{ARS}=0.653$ & $\mathrm{P}<0.001$ \\
Average adjusted R-squared (AARS) & $\mathrm{AARS}=0.647$ & $\mathrm{P}<0.001$ \\
Tenenhaus GoF (GoF) & $\mathrm{GOF}=0.676$ & $>=0.1$ (Small); $>0.25$ (Medium); $>0.36$ (Large) \\
\hline
\end{tabular}

Table 4 shows the Average Path Coefficient (APC) is 0.176 and a $P<0.001$. This explains that the model has a good fit. Average R-squared (ARS) shows 0.653 and $\mathrm{P}<0.001$ indicating that the numbers meet the criteria. The Average Adjusted R-squared (AARS) shows 0.647 and $\mathrm{P}<0.001$ which also explains that the number meets the criteria. The resulting Goodness of Fit is $0.676>0.36$ which explains that the model is declared fit.

\subsection{Hypothesis testing}

Table 5 below shows the results of hypothesis test.

Table 5: Hypothesis testing

\begin{tabular}{llcl}
\hline Hypothesis & P-Values & $\begin{array}{c}\text { Standard of } \\
\text { measurement }\end{array}$ & Results \\
\hline Hypothesis 1 & 0.044 & $\mathrm{P}<0.05$ & Accepted \\
Hypothesis 2 & 0.037 & $\mathrm{P}<0.05$ & Accepted \\
Hypothesis 3 & 0.079 & $\mathrm{P}<0.05$ & Rejected \\
Hypothesis 4 & $<0.001$ & $\mathrm{P}<0.05$ & Accepted \\
Hypothesis 5 & $<0.001$ & $\mathrm{P}<0.05$ & Accepted \\
Hypothesis 6 & $<0.001$ & $\mathrm{P}<0.05$ & Accepted \\
Hypothesis 7 & 0.294 & $\mathrm{P}<0.05$ & Rejected \\
Hypothesis 8 & 0.064 & $\mathrm{P}<0.05$ & Rejected \\
Hypothesis 9 & 0.110 & $\mathrm{P}<0.05$ & Rejected \\
Hypothesis 10 & 0.051 & $\mathrm{P}<0.05$ & Rejected \\
Hypothesis 11 & $<0.001$ & $\mathrm{P}<0.05$ & Accepted \\
\hline
\end{tabular}

To determine the results of a hypothesis decision, $\mathrm{P}<0.05$ shows that hypothesis is accepted and vice versa if $\mathrm{P}>0.05$ then the hypothesis is rejected. Based on table 4 above, it can be explained that the P-Values in Hypothesis 1, which is 0.044, explains that Ease of use affects Attitude (accept H1). Furthermore, the PValues in Hypothesis 2, which is 0.037, explains that Display application affects Attitude towards using (accept H2). P-Values in Hypothesis 3 which is 0.079, explains that Responsiveness has no effect on Attitude (reject H3). Then the P-Values on Hypothesis 4, which is $<0.001$, explains that Customization 
influences Attitude towards using (accept H4). P-Values on Hypothesis 5, which is $<0.001$, explains that guarantee influences Attitude (accept H5). Next, the P-Values in Hypothesis 6, which is $<0.001$, explains that Ease of use influences Loyalty (accept H6). P-Values on Hypothesis 7 which is 0.294 , which explains that the Display application has no effect on Loyalty (reject H7). Furthermore, the P-Values in Hypothesis 8 which is 0.064, explains that Responsiveness has no effect on Loyalty (reject H8). The P-Values on Hypothesis 9 which is 0.110 explain that Customization has no effect on Loyalty (reject H9). The P-Values on Hypothesis 10, which is 0.051, explains that guarantee has no effect on Loyalty (reject H10). Hypothesis 11 shows P-Values of $<0.001$ where these results explain that Attitude influences Loyalty (accept H11).

\subsection{Coefficient of determination}

R-Square 0.70 shows that Ease of use, Appearance in applications, Responsiveness, Adjustment, and Guarantee influence the Attitude towards using of $70 \%$. Furthermore, the R-Square 0.58 explains that Attitude influences loyalty of $58 \%$ (Table 6). Based on these results, it can be further explained that from the research model used in this study the independent variables (Ease of use, Appearance in applications, Responsiveness, Adjustment, and Guarantee) predict the dependent variable (Attitude towards using) quite strongly. Meanwhile, Attitude towards using predicts loyalty moderately.

Table 6: Coefficient of determination

\begin{tabular}{lc}
\hline Variable & \% \\
\hline Attitude towards using. & 70 \\
Loyalty & 58 \\
\hline
\end{tabular}

\section{Discussion}

The first result in this study explains that ease of use affects the attitude of using application-based modes of transportation. Self-efficacy with different age, occupation, and educational backgrounds is a consideration in creating ease of use of transportation mode applications. In addition, aspects of the application system, namely ease of use and navigation, no error/crash are important factors in influencing usage behaviour (Shah, 2020). The results of this study supports research conducted by Kanchanatanee, Suwanno, \& Jarernvongrayab (2014) on the ease of use of E-marketing. This also supports the results of research by G.Taylor \& Strutton (2010). However, in research conducted by Dwilaksono, Handayani, \& Fauziyah, (2018) in an online shopping, ease of use was not proven to affect attitudes to use. Second, this study explains that the appearance of the application affects usage attitudes. As an application that is a routine or urgent need, a display on the application can encourage attitudes in application use. A neat, easyto-understand and attractive appearance can shape individual preferences in using an application. In addition, the information that is updated regularly has a good impact on user satisfaction (Homniem \& Pupat, 2020). The results of this study are in line with research conducted by Le \& Nguyen (2014) with studies on website display. However, this rejects the result of research conducted by Huang (2014) where the appearance of a website application does not affect usage attitudes. Furthermore, this study explains that the responsiveness of the services provided has no effect to the attitude of using application-based modes of transportation. The use of repeated transportation mode applications for a long time forms a memory for the user of the stages and processes that exist, starting from ordering, traveling, completing to the point of destination to complaints. Therefore, service responsiveness to a service, especially in application-based transportation services, is not the main factor determining usage attitudes. This also explains that with the existence of social media, the speed in responding to customer complaints on applications is less attractive to customers. This result is interesting and contradicts Hendrayati et al., (2020) which explains that in an effort to shape the behaviour of satisfied users, responsiveness in responding to customer complaints is a key factor. In other studies Rana, Osman, \& Othman (2015) and Carolyn \& Andaleeb (2006) explained that responsiveness affects consumer attitudes to take further action. The next result explains that service adjustment factor offered by service providers affects usage attitudes. In online- 
Michael Christian et al., Adv. J Social Sci.; Vol. 8, Issue 1, pp: 25-36, 2021

based businesses that use applications or websites, adjustments to services that are consistently made can create a sense of liking and satisfaction from users. The latest available information and offers provided on the mode of transportation application affects usage attitudes. This supports research conducted by $\mathrm{Ha} \&$ Janda (2014) which also has the same result as Kang \& Kim (2012) which explains that e-mass customization affects purchase intention. The fifth result of this study explains that the service guarantee provided to users affects usage attitudes. The consistency of the prices displayed, the promos given, the driver's data, the suitability of the mode of transportation used, vehicle worthiness, driving ability and the estimated travel time are factors that are closely related to the guarantee of transportation mode services. This supports research conducted by Suhartanto, Clemes, Februadi, Suhaeni, \& Loveldy, (2020) which explains that aspects such as driver and vehicle quality shape the behaviour of satisfied customers. In addition, these results also reinforce the research conducted by Ullah \& Islam (2011) which explains that service guarantee affects user behaviour for both short-term guarantee and long-term guarantee.

Next, this study also explains that the ease of use of the application affects loyalty. As explained above, the ease of use of an application can determine the user's attitude to like or dislike the application used. Kuswanto, Sundari, Harmadi, \& Hariyanti (2020) explains that in the context of online services on application-based transportation, usage is closely related to the quality of the existing system in the application itself which directly impacts user satisfaction and loyalty indirectly. In the long term it will determine whether the user will continue to use the existing mode of transportation application. This supports the research conducted by Tu, Fang, \& Lin (2012) on a study of the e-auction marketplace. Then Al-Momani \& Noor, (2009) also explained that the ease of use factor affects e-CRM performance. Furthermore, in terms of the appearance of the application, this study explains that display in the application does not affect user loyalty. As explained before, the appearance of an attractive and easy-to-use application only affects usage attitudes but does not form a long-term relationship impact. The result of this study is different from the result of research conducted by Chang (2015) which explains that the appearance of mobile applications affects user loyalty. The appearance of an application also has an impact on customer reactions to take action (Wang et al., 2015). In the eighth result, this study explains that the responsiveness of application-based transportation modes also does not affect the loyalty. Along with continuous use, customer service as a form of service responsiveness is no longer prioritized. Coupled with the sophistication of technology contained in the smartphone operating system, it allows obstacles related to the responsiveness of the application system to not occur. This supports the research conducted by Leninkumar (2016) where responsiveness is not significant to user loyalty. However, this result contrasts with the research conducted by Hendrayati et al., (2020) where responsiveness which is part of service quality is still an important thing that affects the loyalty of users of application-based transportation modes. Further results in this study explain that service adjustment factors made by service providers has no effect user loyalty. Along with the number of more attractive offerings from competitors forming the intention of continually being doubted. The user prefers which offer is more attractive right away, so to form a loyal usage attitude requires consistent effort to adjust attractive services. This is same as the result of research conducted by Fels, Falk, \& Schmitt (2017) which explains that adjustments do not always shape user loyalty. In relation to the attitude of users to reorder application-based modes of transportation, Homniem \& Pupat (2020) suggests providers must follow technology standards and update the application. The next result explains that the guarantee factor does not affect loyalty. The lure of the warranty offered does not create user loyalty. These efforts only lasted at the user's preferred stage of using application-based modes of transportation at that time, not for the long term. This rejects the results of research conducted by Hashem (2010) which states that guarantees have an effect on loyalty. This result also rejects the research conducted by Suhartanto, Clemes, Februadi, Suhaeni, \& Loveldy (2020) where service guarantees such as vehicles used in good condition, ability to drive, duration of travel time, and comfort in driving are important factors in shaping user loyalty for application-based transportation modes. Other result of this study explains that attitude towards using affects loyalty. This explains that a positive attitude from the experience of using application-based modes of transportation can form a long-term use attitude that reflects user loyalty. This 
Investigating the Determinants of App-based Land Transportation User Loyalty in Jakarta Using PLS-SEM Framework

supports the research conducted by Widjaja, Astuti, \& Manan (2019) which states that there is an influence between the attitudes of satisfied users on Gojek user loyalty as an application-based mode of transportation in Indonesia. This result is also in line with research Abadi, Nursyamsi, \& Syamsuddin (2020) which explains that satisfied users will be loyal.

\section{Conclusion}

Maintaining customer loyalty is not an easy task for application-based transportation service providers, especially for application-based transportation customers in Jakarta. So many aspects of service quality are related to customer behaviour and loyalty. In line with this, this study proves that attitude towards using affects the loyalty of users of application-based transportation modes. In relation to user behaviour, it is important to consider the ease of use of application-based transportation mode ordering applications. This is because it is well known that technological developments affect device and application systems. Apart from being an easy-to-use ordering application, the aesthetic settings of the application display and customisation also influence user behaviour. Therefore, it is necessary to consider continuing to make updates to the appearance of the application. One of the interesting things about this research is that the customer complaint patterns have shifted. Customers prefer to submit complaints on social media than on its applications. This makes customers no longer put speed in responding to customer complaints as important. Furthermore, this research also proves that the service guarantee still affects user behaviour. In relation to the long-term effect of loyalty, the ease of use of the application is an important determinant, while other factors (display application, responsiveness, customization, and guarantee) are not proven. This emphasizes that with the development of technology in application devices and systems, customers primarily want transportation mode booking applications to remain easy to use. Application-based services should provide ease of use.

\section{Declarations}

\subsection{Study Limitations}

Although this study provides interesting results, it has limitation. Along with the expansion carried out by application-based transportation service providers to other urban areas that have complex problems in the field of land transportation, sub-urban areas can be considered for further research to enrich the results of research on the use of application-based modes of transportation for regional characteristics a more diverse range.

\subsection{Acknowledgements}

The authors are grateful to the study participants for their time to participate in the study.

\subsection{Informed Consent}

Informed written consent was obtained from the respondent prior to administering the questionnaire explaining the research topic, respondent criteria required and ensuring privacy and confidentiality. Data is collected anonymously and securely placed with limited access only to the research team. Confidentiality of all records is maintained.

\subsection{Competing Interests}

The authors declare that no conflict of interest exists.

\section{How to Cite this Article:}

Christian, M., Jasfar, F., \& Hady, H. (2021). Investigating the Determinants of App-based Land Transportation User Loyalty in Jakarta Using PLS-SEM Framework. Advanced Journal of Social Science, 8(1), 25-36. https://doi.org/10.21467/ajss.8.1.25-36 
Michael Christian et al., Adv. J Social Sci.; Vol. 8, Issue 1, pp: 25-36, 2021

\section{References}

Abadi, R. R., Nursyamsi, I., \& Syamsuddin, A. R. (2020). Effect of Customer Value and Experiential Marketing to Customer Loyalty with Customer Satisfaction as Intervening Variable (Case Study on Gojek Makassar Consumers). The Asian Journal of Technology Management, 13(1), 82-97. https://doi.org/10.12695/ajtm.2020.13.1.6

Al-Momani, K., \& Noor, N. A. M. (2009). E- Service Quality, Ease of Use, Usability and Enjoyment as Antecedents of E-CRM Performance: An Empirical Investigation in Jordan Mobile Phone Services. The Asian Journal of Technology Management, 2(2), 50-63.

Allen, J., Muñoz, J. C., \& Ortúzar, J. de D. (2019). On the effect of operational service attributes on transit satisfaction. Transportation. https://doi.org/0.1007/s11116-019-10016-8

Amponsah, C. T., \& Adams, S. (2016). Service quality and customer satisfaction in public transport operations. Int. J. Services and Operations Management, 25(4), 531-549.

Anderson, R., Condry, B., Findlay, N., Brage-Ardao, R., \& Li, H. (2014). Measuring and Valuing Convenience: A Review of Global Practices and Challenges from the Public Transport Sector. Retrieved from https://www.oecd-ilibrary.org/transport/valuing-convenience-inpublic-transport/measuring-and-valuing-convenience_9789282107683-3-en

Azzahro, F., Adil, M. A., Fathurrahman, A., Sectianri, A. F., Halimah, N. L., Hidayanto, A. N., \& Yohanes, A. Y. L. (2020). Examining Gojek Drivers' Loyalty: The Influence of Gojek's Partnership Mechanism and Service Quality. 2020 Fifth International Conference on Informatics and Computing (ICIC), 1-5. https://doi.org/10.1109/ICIC50835.2020.9288612

Carolyn, C., \& Andaleeb, S. S. (2006). Customer satisfaction in the restaurant Industry: an examination of the transactionspecific mode. Journal of Services Marketing, 20(1), 3-11.

Chang, C.-C. (2015). Exploring mobile application customer loyalty: The moderating effect of use contexts. TelecommunicationsPolicy, 113. https://doi.org/10.1016/j.telpol.2015.07.008

Cheba, K., \& Saniuk, S. (2016). Sustainable urban transport - the concept of measurement in the field of city logistics. Transportation Research Procedia, 16, 35-45.

Dwilaksono, Y., Handayani, S. D., \& Fauziyah, F. (2018). Effect Of Usefulness, Ease Of Use, Risk, Product Involvement, And Subjective Norms To A Person's Attitudes And Intentions Of Using Online Shopping Among Students In Yogyakarta. International Journal of Business Quantitative Economics and Applied Management Research, 4(8), 1-9.

Eboli, L., \& Mazzulla, G. (2012). Performance indicators for an objective measure of public transport service quality. European Transpor/Trasporti Europei, 51(51).

El-Manstrly, D., \& Harrison, T. (2013). A critical examination of service loyalty measures. Journal of Marketing Management, 29(15-16), 1834-1861. https://doi.org/10.1080/0267257X.2013.803139

Fels, A., Falk, B., \& Schmitt, R. (2017). User-driven customization and customer loyalty: A survey. Procedia CIRP, 60, 410 - 415. https://doi.org/10.1016/j.procir.2017.02.013

G.Taylor, D., \& Strutton, D. (2010). Has e-marketing come of age? Modeling historical influences on post-adoption era Internet consumer behaviors. Journal of Business Research, 63(9-10), 950-956. https://doi.org/10.1016/j.jbusres.2009.01.018

Ha, H.-Y., \& Janda, S. (2014). The effect of customized information on online purchase intentions. Internet Research, 24(4), 496-519. https://doi.org/10.1108/IntR-06-2013-0107

Hair, J. F., Black, W. C., Babin, B. J., \& Anderson, R. E. (2014). Multivariate Data Analysis (7th ed.). Essex: Pearson Education Limited.

Hashem, T. N. (2010). The impact of service guarantees on customer loyalty at Jordanian communications companies. Journal of Accounting and Management and Insurance, (14), 1-29.

Hendrayati, H., Askolani, A., Achyarsyah, M., Sudrajat, C. T., \& Syahidah, R. K. (2020). E-Service Quality and Price to Build Online Transportation Loyalty in Indonesia. Journal of Management and Marketing Review, 5(1), 16-30.

Hickman, R., Fremer, P., Breithaupt, M., \& Saxena, S. (2011). Changing Course in Urban Transport An Illustrated Guide. Manila: Asian Development Bank (ADB) - The Deutsche Gesellschaft für Internationale Zusammenarbeit (GIZ).

Hidayati, I., Yamu, C., \& Tan, W. (2020). Realised pedestrian accessibility of an informal settlement in Jakarta, Indonesia. Journal of Urbanism: International Research on Placemaking and Urban Sustainability, 1-23. https://doi.org/10.1080/17549175.2020.1814391

Homniem, C., \& Pupat, N. (2020). The Factors Influencing Thai Passenger's Intention To Reuse Grab Car Service In Bangkok. AU-GSB EJournal, 13(1), 41-51.

Huang, S. (2014). The impact of context on display ad effectiveness: Automatic attitude activation and applicability. Electronic Commerce Research and Applications, 13(5), 341-354. https://doi.org/10.1016/j.elerap.2014.06.006

Hussein, A. S., \& Hapsari, R. (2014). How Quality, Value And Satisfaction Create Passenger Loyalty: An Empirical Study On Indonesia Bus Rapid Transit Passenger. The International Journal of Accounting and Business Society, 22(2), 95-115.

Jao-Hong, C., Chien Yuan, L., Huei-Ping, C., \& Chun-Liang, O. (2010). The Service Quality Analysis of Public Transportation System using PZB Model- Dynamic Bus Information System. The 40th International Conference on Computers \& Industrial Engineering. Awaji Island: IEEE.

Kanchanatanee, K., Suwanno, N., \& Jarernvongrayab, A. (2014). Effects of Attitude toward Using, Perceived Usefulness, Perceived Ease of Use and Perceived Compatibility on Intention to Use E-Marketing. Journal of Management Research, 6(3), 1-13. https://doi.org/10.5296/jmr.v6i3.5573

Kang, J.-Y. M., \& Kim, E. (2012). e-Mass customisation apparel shopping: effects of desire for unique consumer products and perceived risk on purchase intentions. International Journal of Fashion Design, Technology and Education, 1-13. https://doi.org/10.1080/17543266.2011.641593

Kock, N. (2018). WarpPLS@ User Manual: Version 6.0 (6.0). Retrieved from http://cits.tamiu.edu/WarpPLS/UserManual_v_6_0.pdf

Kuswanto, A., Sundari, S., Harmadi, A., \& Hariyanti, D. A. (2020). The determinants of customer loyalty in the Indonesian ridesharing services: offline vs online. Innovation \& Management Review, 17(1), 75-85. https://doi.org/10.1108/INMR-05-2019-0063

Lai, W.-T., \& Chen, C.-F. (2011). Behavioural intentions of public transit passengers - the roles of service quality, perceived value, satisfaction and involvement. Transport Policy, 18(2), 318-325.

Le, T. D., \& Nguyen, B.-T. H. (2014). Attitudes Toward Mobile Advertising: A Study Of Mobile Web Display And Mobile App Display 
Investigating the Determinants of App-based Land Transportation User Loyalty in Jakarta Using PLS-SEM Framework

Advertising. Asian Academy of Management Journal, 19(2), 87-103.

Lee, C.-Y., Tsao, C.-H., \& Chang, W.-C. (2015). The relationship between attitude toward using and customer satisfaction with mobile application services: An empirical study from the life insurance industry. Journal of Enterprise Information Management, 28(5), 680697. https://doi.org/10.1108/JEIM-07-2014-0077

Leninkumar, V. (2016). The Effect of Service Quality on Customer Loyalty. European Journal of Business and Management, 8(33), 44-49.

Mokonyama, M., \& Venter, C. (2013). Incorporating customer satisfaction in public transport contracts - a preliminary analysis. Research in Transportation Economics, 39(1), 58-66.

Mugion, R. G., Toni, M., Raharjo, H., Pietro, L. Di, \& Sebathu, S. P. (2018). Does the service quality of urban public transport enhance sustainable mobility? Journal of Cleaner Production, 174, 1566-1587. https://doi.org/10.1016/j.jclepro.2017.11.052

Nadi, P. A., \& Murad, A. (2019). Modelling Sustainable Urban Transport Performance in the Jakarta city Region: A GIS Approach. Sustainability, 11(1879), 1-28. https://doi.org/10.3390/su11071879

Negi, R. (2010). Determining satisfaction through customer-perceived service quality and value: Evidence from Ethiopian Telecommunications. Int. J. Services and Operations Management, 7(3), 333-350.

Ng, P. Y., \& Phuong, P. T. (2015). From motor biking to public transportation what matters in Hanoi? World Journal of Management, 6(2), $1-15$.

Oliver, R. . (2010). Satisfaction: A Behavioral Perspective on the Consumer. M.E. Sharpe, Armonk.

Rahadianto, N. A., Maarif, S., \& Yuliati, L. N. (2019). Analysis of intention to use transjakarta bus. Independent Journal of Management \& Production, 10(1), 301. https://doi.org/10.14807/ijmp.v10i1.748

Rana, S. M. S., Osman, A., \& Othman, Y. H. (2015). Factors Affecting Purchase Intention of Customers to Shop at Hypermarkets. Mediterranean Journal of Social Sciences, 6(3), 429-434. https://doi.org/10.5901/mjss.2015.v6n3p429

Ribbink, D., Riel, A. C. R. van, Liljander, V., \& Streukens, S. (2004). Comfort your online customer: quality, trust and loyalty on the internet. Managing Service Quality: An International Journal, 14(6), 446-456. https://doi.org/10.1108/09604520410569784

Rita, S., \& Ganesan, V. (2010). Assessment of QOS for Public Bus Transport System -A SERVQUAL Based Kano Approach. Advances In Management, 3(4), 115-142.

Shah, T. R. (2020). Service quality dimensions of ride-sourcing services in Indian context. Benchmarking: An International Journal, 28(1), 249-266. https://doi.org/10.1108/BIJ-03-2020-0106

Siangta, S., Solichin, J., \& Hendriana, E. (2020). Effect of Service Quality and Sales Promotion on Customer Loyalty in Online Transportation Services. Solid State Technology, 63(5), 4561-4575.

Suhartanto, D., Clemes, M., Februadi, A., Suhaeni, T., \& Loveldy, Z. A. C. (2020). Modelling Passenger Loyalty Towards App- Based Motorcycle Taxi. Asian Academy of Management Journal, 25(1), 43-60. https://doi.org/10.21315/aamj2020.25.1.3

Sumaedi, S., Bakti, I. G. M. Y., \& Yarmen, M. (2012). The impact study of public transport passengers behavioral intentions: the roles of service quality. Perceived sacrifice, perceived value, and satisvaction (case study: paratransit passengers in Jakarta, Indonesia). International Journal for Traffic and Transport Enginerring, 2(1), 83-97.

Tu, C.-C., Fang, K., \& Lin, C.-Y. (2012). Perceived Ease of Use, Trust, and Satisfaction as Determinants of Loyalty in e-Auction Marketplace. Journal Of Computers, 7(3), 645-652.

Ullah, G. M. S., \& Islam, M. R. (2011). Effects of Warranty on Purchase Decision of Electronic Products: An Empirical Research from the Perspective of Bangladesh. Industrial Engineering Letters, 1(1), 13-23.

Wang, Z., Singh, S. N., Li, Y. J., Mishra, S., Ambrose, M., \& Biernat, M. (2015). Effects of Employees' Positive Affective Displays on Customer Loyalty Intentions: An Emotions-As-Social-Information Perspective. Academy of Management Journal, 1-51. https://doi.org/10.5465/amj.2014.0367

Widjaja, A., Astuti, W., \& Manan, A. (2019). The Relationship between Customer Satisfaction and Loyalty: Evidence on Online Transportation Services in Indonesia. International Journal of Advances in Scientific Research and Engineering (IJASRE), 5(4), 214222. https://doi.org/10.31695/IJASRE.2019.33166

Zailani, S., Iranmanesh, M., Masron, T. A., \& Chan, T.-H. (2016). Is the intention to use public transport for different travel purposes determined by different factors? Transportation Research Part D, 49, 18-24.

Publish your research article in AIJR journalsOnline Submission and Tracking

$\checkmark$ Peer-Reviewed

$\checkmark \quad$ Rapid decision

$\checkmark \quad$ Immediate Publication after acceptance

$\checkmark \quad$ Articles freely available online

$\checkmark \quad$ Retain full copyright of your article.

Submit your article at journals.aijr.in
Publish your books with AIJR publisherPublish with ISBN and DOI. Publish Thesis/Dissertation as Monograph. Publish Book Monograph. Publish Edited Volume/ Book. Publish Conference Proceedings Retain full copyright of your books.

Submit your manuscript at books.aijr.org 